
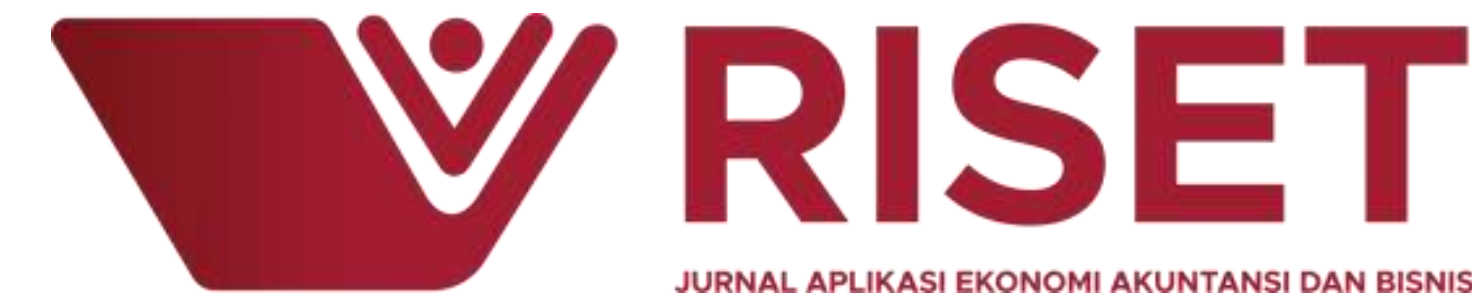

JURNAL APLIKASI EKONOMI AKUNTANSI DAN BISNIS

\title{
STRENGTHENING INNOVATION AND ENTREPRENEURSHIP IN IMPROVING MSMES COMPETITIVENESS
}

\author{
Suharyati ${ }^{1)}$, Edimarwan ${ }^{2)}$ \\ ${ }^{1,2)}$ Faculty of Economics and Business - UPN Veteran Jakarta,
}

\section{INFO ARTIKEL}

Strenghthening Innovation And Entrepreneurship In Improving SMES Competitivenes

Submitted:

28 - Januari - 2020

Revised:

14 - Maret - 2020

Accepted:

30 - Maret - 2020

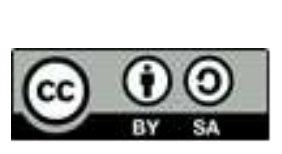

\begin{abstract}
MSMEs are able to penetrate Indonesia's GDP by $60 \%$, but the contribution to Indonesia's exports is still lagging behind compared to Southeast Asian countries such as Thailand and the Philippines which have high competitiveness. The economic potential of the Parung district in 2017, seen from the perspective of the MSMEs is at a growth stage. This research analyzes and proves that Innovation and Entrepreneurship influences the competitiveness of MSMEs in Parung district. The population in this study were the MSMEs of Parung subdistrict registered in the MSMEs forum, the sample used was 60 respondents with the Purposive Sampling method. The method used to analyze and interpret data is descriptive statistical analysis using a variance-based Structural Equation Model or called Partial Least Square. The results obtained by all indicators on all variables of this study have met the convergent validity test. The Average Variance Extracted (AVE) value indicates that the entire construct declared valid. The cronbach's alpha value of all constructs indicating that the construct is declared reliable. The direction of the relationship between Innovation and Entrepreneurship is positive, and Innovation has a significant effect on competitiveness. The direction of the relationship between Entrepreneurship and Competitiveness is positive and Entrepreneurship has a significant effect on Competitiveness. Overall it can be concluded that both Innovation and Entrepreneurship contribute directly to Competitiveness. Thus the increase in Innovation and Entrepreneurship directly affects the improvement of MSMEs Competitiveness.
\end{abstract}

Keywords: Competitiveness, Innovation, Entrepreneurship, MSMEs 


\section{Introduction and Objectives and Goals}

The MSMEs in Indonesia has an important role on economic and development growth and have an important contribution in unemployment problems (Sutrisno, 2016). (Putra D. A., 2018), (Mutmainah, 2016) writes that the contribution of MSMEs to Gross Domestic Product (GDP) has exceeded $60 \%$, however, the contribution to Indonesia's exports is still left behind when compared to Southeast Asian countries such as Thailand and the Philippines. MSMEs in ASEAN countries have a higher competitiveness, not only to the domestic market but also to foreign markets. This is due to the main problems faced by Indonesian MSMEs, which is the lack of technological capability, quality of Human Resources (HR), marketing access, access to capital and networks that are unable to compete with neighbour countries (SINDO, 2016). Similarly, the Chairperson of the Indonesian Chamber of Commerce and Industry Rosan Roeslani said most of the MSME entrepreneurs did not have access and information to the global market. The MSME business has several weaknesses in operating such as marketing difficulties, access to a very limited funding sources, limited human resources (HR), raw material difficulties, limited innovation and technology.

As explained by (Sandy, 2016), that increasing MSMEs competitiveness encourages economic growth, business mentoring for standardization of export product quality can also be conducted to expand market access for MSMEs, increasing access to capital can be done by providing financing schemes for MSMEs that integrated with capacity building activities and group empowerment (social capital). Meanwhile, to facilitate business activities, one thing that can be done is to facilitate licensing and provide tax incentives. While infrastructure improvements can be done by building a database for MSMEs to overcome the information gap issue. Therefore the cooperation from various parties is extremely needed, so MSMEs can have the good competitiveness to create good quality of Indonesian economic growth.

(Sumaryono, 2017) in his writings, said that building and enlarging MSME competitiveness is indeed not easy. Of course, every effort will be different and there is the need for uniqueness in terms of geographical and business fields. There are a number of challenges that need to be addressed to encourage the competitiveness of MSMEs in order to protect quality, have skills, get access to funding, and reach the market. The existence of information technology and communication can be used effectively, especially for export marketing. Information technology (IT) plays a big role in helping MSMEs. The role of government is very necessary in encouraging the success of MSMEs in gaining access to expand the marketing network quickly and easily. Utilization of the web or e-commerce is a need for every entrepreneur especially MSMEs in improving competitiveness. The Digital IT-based MSMEs are believed to be one of the hopes to bring Indonesia's economy into the better future.

(Auliani, 2018) mentions that the disruption era is marked by the emergence of various innovations, technologies, platforms and new business models. Fintech is slowly starting to erode the conventional sacrificial business. Companies such as Gojek and Grab, service operators, offer a business sharing model. The MSMEs sector, in the era of disruption, opened up great opportunities for MSMEs to move up the class. An innovative start-up company has cooperated with and empowered MSMEs. The Demographic Institute Survey of the Faculty of Economics and Business Universitas Indonesia (LD FEB UI) explains that the era of disruption has helped many MSMEs. The emergence of technology companies such as Go-Jek has a big influence on the improvement of MSME earnings. 
(Budianto, 2018) the Ministry of Communication and Information encourage all the economic sectors to utilize information and communication technology (ICT) or making online transactions. These actions are considered to give added to entrepreneurs. Utilization of ICTs can help increase market access, increase income and expansion. In fact, the expectation is that transactions will reach to overseas transaction. (Putra, 2018), the use of proven digital technology can accelerate the growth of micro, small and medium enterprises in Indonesia.

(Sopia, 2017) The Bogor Regency Government seeks to increase people's purchasing ability through the optimization of micro, small and medium enterprises (MSMEs). Purchasing ability becomes an important indicator when it is connected to the calculation of the human development index (HDI). (Ramadhan I. , 2017) The MSMEs in Bogor Regency want the full attention of the Regional Government to increase Human Resources, capital and legality, and also marketing of MSME products. Product marketing is conducted through exhibitions, online, restaurants and hotels,

One of the districts that have great contribution in increasing the regional economic potential is Parung district. It has 9 villages which are Iwul, Jabon Mekar, Pamegar Sari, Parung, Waru, Waru Jaya, Bojong Sempu, Bojong Indah, and Cogreg. Business activities that spread in the Parung district consists of 1,301 Small Enterprises, 299 Medium-sized Enterprises, and 39 Large Enterprises, so that as a whole, Parung District has 1,630 MSMEs. The existence of main business products in in the village of Parung district, which are: Iwul Village: Tofu, Catfish floss; Jabon Mekar village: Ornamental Plants; Pamegar Sari village: Ornamental Plants; Parung Village: Processed Fish, Bojong Sempu Village: Tofu; Bojong Indah village: Kembang Goyang cake; Cogreg village: Catfish products, while Waru village and Waru Jaya village do not have main business products.

Based on the results of a study mapping of economic potential seen from the perspective of MSMEs in the Parung district in 2017 (Suharyati \& Ediwarman, 2019), by using a four-quadrant SWOT analysis, it can be seen that the position of MSMEs is at the growth stage. In this position, a strategy that can be carried out by MSMEs is to increase sales and to obtain higher profits. MSMEs must have long-term planning to achieve success. Financial performance is maintained although this is less influential for MSMEs. It is important for MSMEs to improve product quality, enter new market segments, increase the reach of distribution, communication and information, reduce prices, innovate and improve entrepreneurial skills.

Product development strategy is necessary to be implemented, then the MSMEs must have be brave to look for any opportunities by making various product innovations to be accepted in the market. With a product development strategy and market penetration, it can increase regional economic potential even at the international level. Product development strategies can be carried out by creating new products for existing customers, innovative products, collaboration, research and development. Strategic entrepreneurship is more likely to be succeed when employees have an entrepreneurial mindset: autonomy, innovation, risk taking, pro activity, and competitive aggressiveness. (Hitt, Duane, \& Hoskisson, 2009)

Based on the opportunities and challenges as well as the economic potential of MSMEs in Parung sub-district, the researcher is interested in conducting research with the topic "Strengthening Innovation and Entrepreneurship in Improving the Competitiveness of MSMEs". 


\section{Scope of the problem}

In the era of globalization and disruption that marked by the emerge of various innovations, technologies, platforms, and new business models, this is an opportunity as well as a challenge for Indonesian MSMEs to increase their competitiveness, not only at the national and regional level but also at the international levels. Parung District, an area in Bogor Regency has the economic potential of MSMEs in a growth position. The condition of UMKM in Parung district, Bogor Regency, still not operating optimally and requires the development and innovation of various fields to be able to improve MSMEs performance, so that it has the potential to enhance the competitiveness of MSMEs. For this purpose, a research is necessary to analyze and prove whether innovation and entrepreneurship have an influence on the competitiveness of MSMEs in Parung District, Bogor Regency.

\section{Research Objectives}

The aim of this study is to analyze and prove that innovation and entrepreneurship have an influence on increasing the competitiveness of the MSMEs at micro level in Parung District, Bogor Regency. The results of this study are also expected to be useful for related agencies in Parung Sub-District, Bogor Regency as information materials on the influence of Innovation and Entrepreneurship in enhancing the competitiveness of MSMEs. Therefore, the coaching program for each MSME can be arranged. Then it can enable to create many independent MSMEs that can be developed to increase local competitiveness at the national and international levels. While for SMEs, it is an opportunity to develop business through mentoring and coaching programs towards the Innovation and Entrepreneurship in order to penetrate a wider market.

\section{Literature review}

(Yanah, Nakhwatunnisa, \& Sukarno, 2018) based on the results of the strategy to increase the competitiveness of SME's enterprises, the variable funding, entrepreneurship training, business mentoring and partnerships have positive and significant impact on the competitiveness, meaning that if these variables are improved, it will increase the competitiveness of SMEs in facing the ASEAN economy.

(Andriyanto, 2018) in his research on strengthening the competitiveness of micro small and medium businesses through e-commerce, it can be concluded that the use of IT in implementing e-commerce is a competitive strategy that will increase the competitiveness of MSMEs.

In line with the research of (Pavlova \& Ahmedova, 2017) Opportunities for forming competitive advantages through transfer of technology, the transfer of technology has become an effective tool for competitive micro and macro innovation development. For Bulgarian enterprises, the transfer of technology is a great opportunity to receive processes and effectively use information based on knowledge, increase their overall performance and competitiveness, which is the true basis for further development and prosperity.

(Purnomo, 2017) in his research on strengthening entrepreneurship in enhancing the competitiveness of superior product SMEs in the city of Bandar Lampung, uses indicators in the entrepreneurial model that are flexible, proactive, brave to take risks, experience business, and anticipatory.

(Ahmedova, 2015) The main factor, identified as an important impact on the competitiveness of companies is access to finance, innovation activities, activities 
related to intellectual property, internationalization, application of best practices. For the purposes of this research, company competitiveness is seen as a potential for achieving high productivity, based on a creative approach to human, capital and physical resources.

(Haryono \& Marniyati, 2017) in their research on the effect of market orientation, product innovation, and product quality on business performance in creating competitive advantage, research results show that there is a positive and significant direct influence on Innovation of products towards competitive advantage.

(Fatmawati, Pradhanawati, \& Ngatno, 2016) the results of research on the effect of entrepreneurial orientation on the competitiveness of Angkringan Business in Semarang shows that there is an influence on entrepreneurial orientation towards

(Muslikh, 2015) research concerning on efforts to improve the competitiveness of MSME's products in Tegal Waru tourism village in Bogor Regency, shows that the orientation of the entrepreneurship has a significant influence on innovation; Market orientation has a significant influence on innovation; and Innovation has a significant influence on competitiveness.

(Nurzamzami \& Siregar, 2014) Based on the results of study, the most influential factors on enhancing the business of footwear in the District of Ciomas are human resources, natural resources and the environment, technology, preferences of consumers, and design of product features.

(Burger, 2012) the dimensions characterizing entrepreneurial orientation: Innovation: A firm's tendency to initiate and support new ideas, novelty, experimentation and creative processes that can result in new products, services or technological processes; Pro-activeness: Organizational decision-making through anticipation and following up new opportunities and participating in emerging markets; Acceptance of risks Risks: are accepted in terms of investment decisions and strategic action in face of uncertainty; Collective business capacity: Involves the whole team's skills in dealing with opportunities which may arise.

\section{Measuring Competitiveness}

(Ramadhan, 2017) there are 12 pillars to measure the competitiveness of countries in the world (Global Competitiveness Index) that become the factors of long-term growth and factors in economic growth and welfare are Institutions, Infrastructure, Macroeconomic Environment, Health and Primary Education, Higher Education and Training, Goods Market Efficiency, Labor Market Efforts, Financial Markets, Financial Markets, Financial Markets development, Techological readiness, Market Size, Business Sophistication and Innovations.

(Bank-Indonesia, 2016) the factors that influence MSMEs in Indonesia are human resources, the ease of doing business, the access to capital, market access, infrastructure, logistics and telecommunications, and business cycle. Whereas in Malaysia is Innovation and Technology, HR Development, Financial Access, Market Access, Regulation and Regulation, Infrastructure, and in Myanmar is Climate, Business Access, Market Access, Efficiency and Productivity.

(Ahmedova, 2015) in measuring competitiveness, we attempt to capture and understand these factors which influence or limit the capacity of any particular place to maximize productivity potential and performance. From this perspective, the report focuses on four key thematic areas known to influence the capacity of a given place to achieve its potential: Human capital, Infrastructure, Institutions, Economy. 


\section{Enterprise Competitiveness}

Competitiveness, A.Sergeev, Velev, Avila in (Ahmedova, 2015) Competitive advantages reflect in higher productivity, and then in profitability. A company that is able to develop and uphold such opportunities that provide higher performance and sustainable profitability is considered competitive. In other words, the level of success or achievement of a given industrial company is equivalent to its level of competitiveness. The products competitiveness also appear to include production efficiency, marketing experience and lower administrative costs (Pratten). Enterprise competitiveness is said to refer also to product competitiveness, production efficiency, financial position and organization effectiveness in terms of restructuring and sales and demand stimulation. Enterprise competitiveness is its ability through continuous renewal and improvement to create and maintain sustainable competitive advantages, leading to higher economic performance over long periods.

Based on the analysis and theory that supports competitiveness, then in this study, in measuring the competitiveness of MSMEs, the indicators used are financial access, human resources, market access, product competitiveness, product efficiency, organizational efficiency, infrastructure, business climate.

\section{Competitive Advantage}

Nowadays companies must think about competition and get to know who their competitors are. Companies also need to think not only to manage the products they produce, but also to think about long-term relationships with their customers. The first stage the company must do a competitor analysis to get to know who the competitors are. Competitor analysis is the process of identifying key competitors, assessing their objectives, strategies, strengths and weaknesses and reaction patterns, selecting with competitors to attack or avoid. After the company analyzes its competitors, the second stage is competitive marketing strategies.

(Kotler \& Amstrong, 2012) Competitive Marketing Strategies is strategies that strongly position the company against competitors and give the company the strongest possible competitive advantage. Competitive Advantage, is an advantage over competitors gained by ofering consumers greater value than competitors do. (Kotler \& Keller, Marketing Management, 2012)Competitive advantage is the ability of a company to work in one or more ways that cannot or will not be imitated by competitors. Companies must focus on building customer excellence, then delivering high value and customer satisfaction, which results in high repeat purchases and will ultimately increase company profitability.

(David \& David, 2017) defines competitive advantage as "whatever the company does is better than that of rival companies". When a company can do something that cannot be done by a competitor company or have something that a competitor company wants, then it can represent a competitive advantage.

\section{Entrepreneurship}

(Kuratko, Frederich, \& O'Connor, 2016) The entrepreneur is the aggressive catalyst for change in the world of business. They are independent thinkers who dare to be different in a background of common events. Entrepreneurship in the twenty-first century reveals that man entrepreneurs have certain characteristics in common, including the ability to consolidate resources, management skills, a desire for autonomy and risk taking. Other characteristics include brashness, competitiveness, goal-oriented behaviour, confidence, opportunistic behaviour, intuitiveness, pragmatism, the ability to learn from mistakes and the ability to employ human relations skills. 
(Scarborough, 2012) An Entrepreneur is one who creates a new business in the face of risk and uncertainty for the purpose of achieving profit and growth by identifying opportunities and assembling the necessary resources to capitalize on those opportunities. (Mariotti, 2010) Someone who creates and runs a business is called an entrepreneur. To be entrepreneurial means to think or act like an entrepreneur.

(Hitt, Duane, \& Hoskisson, 2009) Medium and small-sized firms also rely on strategic entrepreneurship when trying to develop innovations as the foundation for profitable growth. This can be successful when employees have an entrepreneurial mindset, namely autonomy, innovativeness, risk taking, pro activeness, and competitive aggressiveness. Entrepreneurship is the process by which individuals or groups identify and pursue entrepreneurial opportunities without being immediately constrained by the resources they currently control.

\section{The Entrepreneurial Profile}

(Scarborough, 2012) The entrepreneurial profile: Desire and willingness to take initiative, Preference for moderate risk, Confidence in their ability to success, Perseverance, Desire for immediate feedbacks, High level of energy, competitiveness, future orientation, Skill at organizing, value of achievement over money.

(Dollinger, 2008) Entrepreneurial profile (Elements and characteristics): Creativity and innovation, resource identification, acquisition, and marshalling, economic organization, opportunity for gain (or increase) under risk and uncertainty.

(Brown \& Ulijn, 2004) Entrepreneurship is a process of exploiting opportunities that exist in the environment or that are created through innovation in an attempt to create value. It often includes the creation and management of new business ventures by an individual or a team. There is a link between creativity and innovation, with new markets, products, processes and technology. Entrepreneurship involves competitive actions to win the market, involves acting to exploit opportunities and involves actors to bear risks.

Based on the definitions of entrepreneurship above, in this study, the indicators used to measure entrepreneurship in the dimensions of characterizing entrepreneurial orientation is: Pro-activeness, Acceptance of risks, Collective business capacity (Burger, 2012).

\section{Innovation:}

(Baer, 2019), There are 3 types of Innovation: Product, Process, and Business Model. Innovation has become such a buzzword it can be hard to remember what it actually means. There are several different ways a company can innovate; they are broken down into three general categories: product, process, and business model.

(Zaidi, 2018), There are different ways an organization can innovate. Essentially, there are three types of innovation: product innovation, process innovation and business model innovation. These types of innovation can include breakthrough innovation or incremental innovation. To stay relevant, all organizations big or small need to consider each of these types of innovation at some stage.

(Kuratko, Frederich, \& O'Connor, 2016) Principles of Innovation: Innovation principles really do exist; Be action oriented; Make the product, process or service simple and understandable; Make the product, process or service customer-based; Start small; Aim high; Try/test/revise; Learn from failures; Follow a milestone schedule; Reward heroic activity; Work.

(Burger, 2012) Five types of innovations (Schumpeter, 1912): Introduction of new products, Introduction of new methods of production, Opening of new markets, 
Development of new sources of supply for raw materials or other inputs, Creation of new market structures in an industry.

(Burger, 2012), Becker\&Cunha (2006) The Organization for Economic Cooperation and Development (OECD): Innovation emerges to entrepreneurs as advantages from the point of view of economical prosperity. It allows developing new products or services for the market as well as it stimulates interest in investing in newborn businesses.

Oslo Manual (OECD,2005), defines innovation as the implementation of a new or significantly improved product (good or service), or process, a new marketing method, or a new organisational method in business practices, workplace organisation or external relations.

(Rogers, 2003) The characteristics of innovations, as perceived by individuals, help to explain their different rates of adoption. Innovations that are perceived by individuals as having greater relative advantage, compatibility, trial ability, and observe ability and less complexity will be adopted more rapidly than other innovations.

(Drucker, 1986) Innovation is a specific instrument for entrepreneurs in a way to explore changes as an opportunity for a different business or services. Entrepreneurs must deliberatively look for innovation sources, changes and their symptoms, which indicate opportunities so that innovation can happen and be successful.

\section{Creation and Innovation:}

(Robbins \& Coulter, 2016) Creativity Versus Innovation. Creativity: the ability to combine ideas in a unique way or to make unusual associations between ideas. Innovation: taking creative ideas and turning them into useful products or work methods.

(Dollinger, 2008) The term creation implies the founder and origin. It is rare for an organization to change ownership without changes in the management and configuration of its resources, but the level of change and innovation determines whether there is entrepreneurship in it. To see how much change is needed, we can rely on the "new combination" category of Schumpeter, i.e. whether new products or services offered, new methods or technologies used, new markets targeted and opened, new sources of supply of raw materials and resources used, a new form of industrial organization created (This is, perhaps, the rarest of all innovations.)

(Brown \& Ulijn, 2004) Innovation is creating something new and implementing it successfully at a market. Innovation deals with processes, products and services, and technology. There is a link with creativity and innovation, with new markets, products, processes and technology. Entrepreneurship involves competitive actions to win the market, involves acting to exploit opportunities and involves actors to bear risks.

\section{Innovation and The Entrepreneurship}

(Zhao, 2006) Innovation is defined broadly to include new products, new processes, new services (including new uses of established products, processes, and services), new forms of organization, new markets, and the development of new skills and human capital. The essence of innovation and entrepreneurship is taking a new idea to market, not imitating a new idea without taking into account the special needs of local markets, and being innovatively and proactively responsive to environmental changes by introducing a new product, process, service, or implementing a distinctive business model.

(Kuratko, Frederich, \& O'Connor, 2016) Innovation is a key function in the entrepreneurial process. Innovation is the process by which entrepreneurs convert 
opportunities (ideas) into marketable solutions. It is the means by which they become catalysts for change. Entrepreneurs face a number of different types of risk. These can be grouped into four basic areas: (1) financial risk, (2) career risk, (3) family and social risk and (4) psychic risk.

Entrepreneurship and innovation are positively related to each other and interact to help an organization to develop: Entrepreneurship and innovation are complementary and the combination of these two factors is vital to organizational success and sustainability in today's dynamic and changing environment; Entrepreneurship and innovation are dynamic and holistic processes in entrepreneurship and innovative organizations.

Based on the theory and the findings of previous studies, in this study the indicators used to measure innovation by using three types of innovation are: Product innovation, Process innovation and Business model innovation.

\section{Hypothesis}

This research hypothesis is based on the theory and the results of previous research to analyze the effect of innovation and entrepreneurship on competitiveness. The research hypothesis was arranged as follows:

$\mathrm{H}_{1}$ : It is assumed that innovation has significant influence on competitiveness.

$\mathrm{H}_{2}$ : It is assumed that entrepreneurship has significant influence on competitiveness.

\section{Methodology}

\section{Operational Definition}

Innovation: Is the value obtained from a questionnaire given to respondents in the dimensions of product innovation, process innovation, and business model innovation. Entrepreneurship: Is the value obtained from a questionnaire given to respondents in the pro-activeness dimension, acceptance of risks, and collective business capacity. Competitiveness: Is the value obtained from a questionnaire given to respondents with indicators of financial access, human resources, market access, product competitiveness, product efficiency, organizational efficiency, infrastructure and business climate.

\section{Variable Measurement}

Table 1. Variable measurement

\begin{tabular}{|l|l|l|}
\hline \multicolumn{1}{|c|}{ VARIABLE } & DIMENSION & \multicolumn{1}{c|}{ INDICATOR } \\
\hline Innovation & Product & 1. Improve product / service quality \\
innovation & 2. Unique and attractive product designs \\
& & $\begin{array}{l}\text { 3. Unique and attractive packaging } \\
\text { 4. There are various sizes available }\end{array}$ \\
\cline { 2 - 3 } & Process & 1. Using technology services \\
& innovation & 2. Different ways of payment \\
& 3. Technological payment methods \\
& 4. The production process uses technology \\
& 5. Professional in serving customers \\
\cline { 2 - 4 } & Business model & 1. Make changes in business practices \\
& innovation & 2. Improve the company's external relations \\
& & 3. Has a network (network / social media) \\
\hline
\end{tabular}




\begin{tabular}{|c|c|c|}
\hline & & $\begin{array}{l}\text { 4. Dare to take risks on changing business } \\
\text { models }\end{array}$ \\
\hline \multirow[t]{3}{*}{ Entrepreneurship } & Pro-activeness & $\begin{array}{l}\text { 1. Monitoring the macro environment } \\
\text { 2. Being able to follow up on new opportunities } \\
\text { 3. Participate in local, regional and international } \\
\text { markets }\end{array}$ \\
\hline & $\begin{array}{l}\text { Acceptance of } \\
\text { risks }\end{array}$ & $\begin{array}{l}\text { 1. Able to accept risk } \\
\text { 2. Being able to make investment decisions } \\
\text { 3. Able to take strategic actions in uncertainty }\end{array}$ \\
\hline & $\begin{array}{l}\text { Collective } \\
\text { business } \\
\text { capacity }\end{array}$ & $\begin{array}{l}\text { 1. Able to work in teams } \\
\text { 2. Able to communicate } \\
\text { 3. Interpersonal skills } \\
\text { 4. Being able to involve the team in seizing } \\
\text { opportunities }\end{array}$ \\
\hline Competitiveness & Competitiveness & $\begin{array}{l}\text { 1. Financial access } \\
\text { 2. Human resources } \\
\text { 3. Market access } \\
\text { 4. Product competitiveness } \\
\text { 5. Product efficiency } \\
\text { 6. Organizational efficiency } \\
\text { 7. Infrastructure } \\
\text { 8. Business Climate }\end{array}$ \\
\hline
\end{tabular}

Source: Data processed

\section{Population, Sample and and Data Collection Techniques}

The population used as objects in this study are entrepreneurs of MSMEs at micro level who are still active in running their business located in the Parung district, Bogor Regency. The sampling technique used is non-probability sampling with the sampling method by using purposive sampling technique. The criteria of sampling are the entrepreneurs of the MSMEs. The sample is restricted only for the entrepreneurs in Parung District, Bogor Regency which has been doing business for 2 years in a row and own or does not belong to the MSMEs member in the Parung district, Bogor Regency. The number of samples is 60 respondents. The type of data used by researchers is primary data, with a measuring instrument in the form of a Likert scale. Likert scale with a scale range from "strongly disagree" marked by score of one (1) to "strongly agree" marked by score of five (5).

\section{Analysis and Hypothesis Test Techniques}

The method used to analyze and interpret data is descriptive statistical analysis using a variance-based Structural Equation Model or called Partial Least Square (SmartPLS software version 3.2.8). According to Ghozali (2014) states that the purpose of PLS is to help research to get the value of latent variables for predictive purposes. The statistical test used is the t test and the coefficient of determination $\left(\mathrm{R}^{2}\right)$ test. Based on the studies that have been outlined, we get this research model as follows: 
Figure 1. Research Model

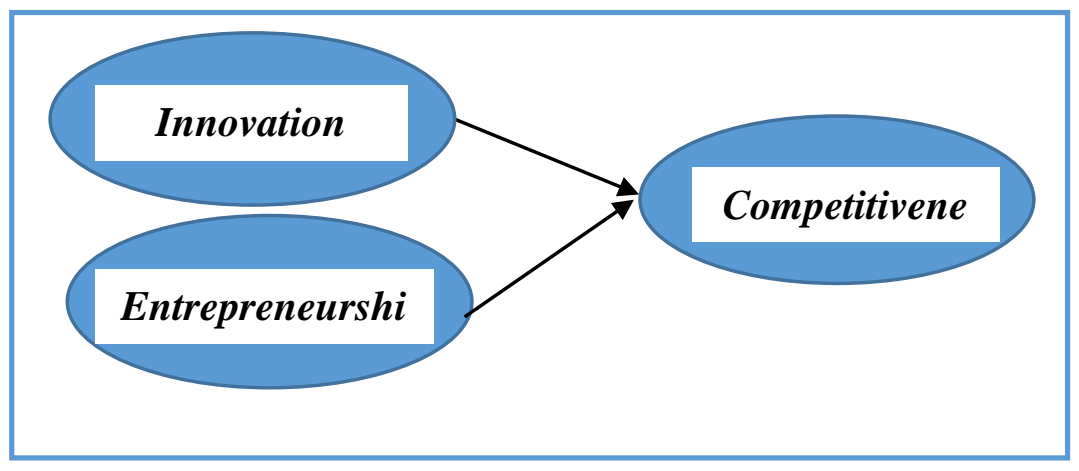

\section{Results}

\section{Description of Research Object}

Bogor Regency is a district in the province of West Java, Indonesia. Bogor Regency consists of 40 sub-districts, divided into a number of villages and sub-districts with a population of 5.8 million people. One of the districts in Bogor regency that has quite a large population is Parung District with a total population of 143,174 inhabitants in 2017. The large number of Population is in line with the MSMEs growth in Parung District, which until 2017 is known to have 1,630 MSMEs. Each village in Parung district has its own business product characteristics. For example, Iwul and Bojong Sempu districts have tofu products and also catfish floss products, Jambon Mekar and Pamegar Sari districts have ornamental plant products, Bojong Indah district has kembang goyang cake products, Cogreg district has catfish products and Parung village has processed fish products.

\section{Descriptive Respondent Data}

In this study, the researcher took respondents with a total of 60 people in accordance with the research plan used for data testing. The respondents of this study are MSMEs in the Parung district, Bogor Regency with the following characteristics:

Figure 2. Data of the Respondent

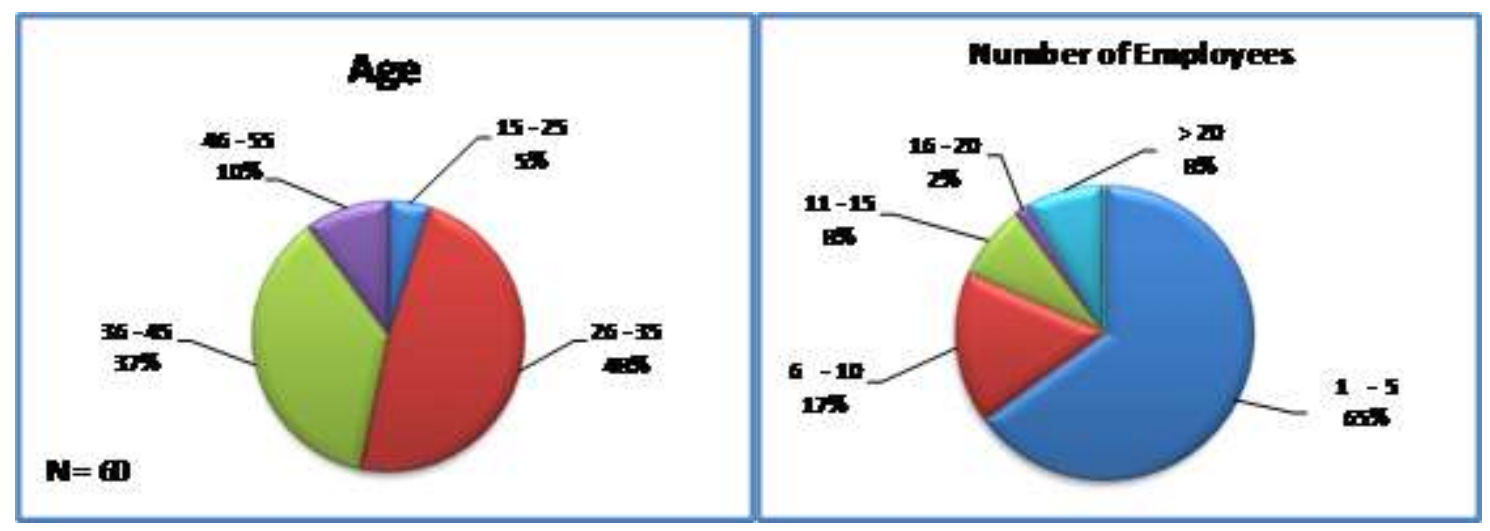



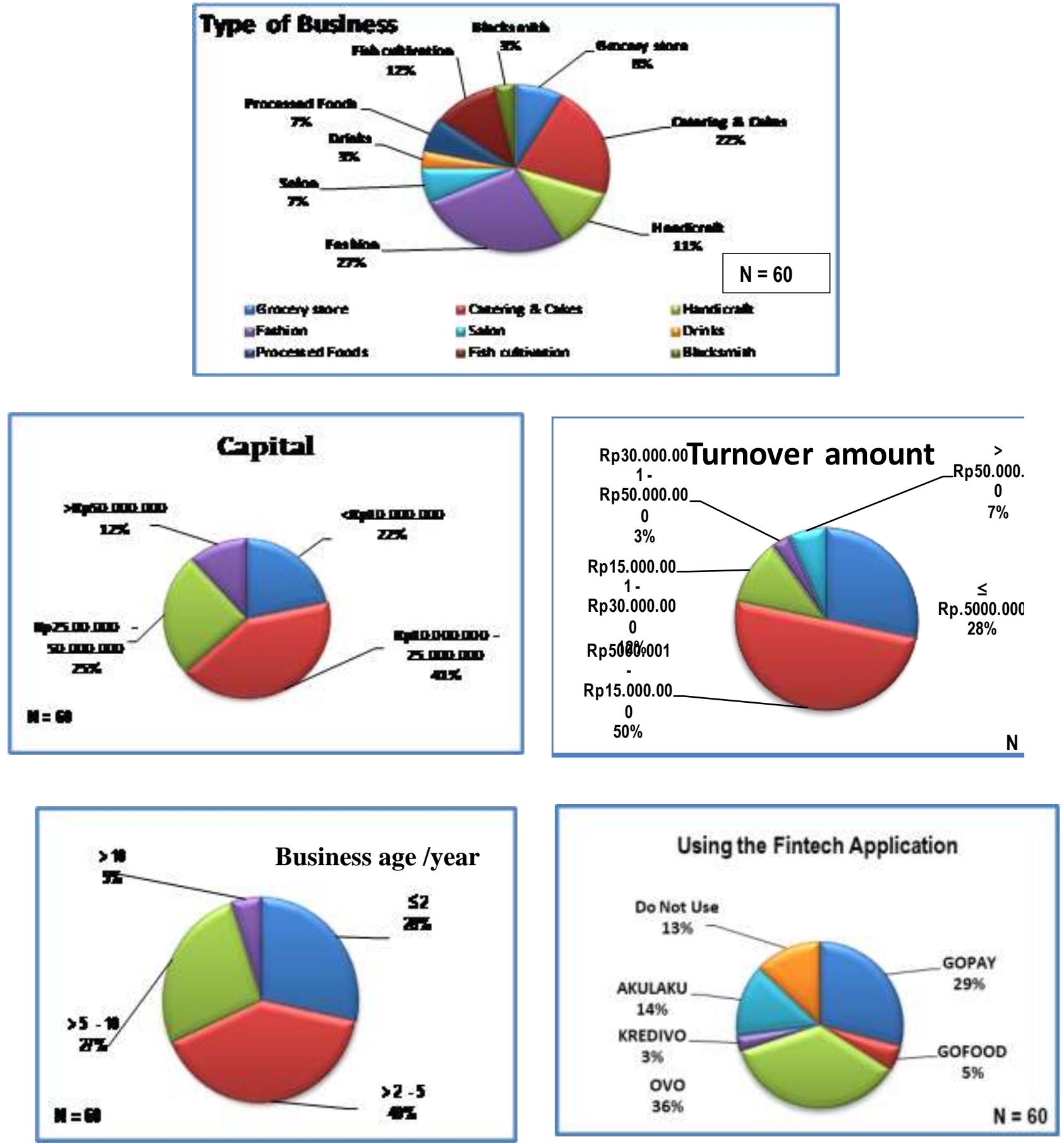

\section{Descriptive Data Analysis}

Below is the calculation of the index value that presents the answers given by respondents to responses to the statement items.

a. Index Value of Respondents' Answers to Innovation Variables

The innovation variables in this study were measured by 13 statements in the dimensions of product innovation, process innovation, and business model innovation. 
The results of the calculation of answers and index scores towards the innovation variables can be seen in the following table:

Table 6. Results of Respondents' Answers to Innovation Variables

\begin{tabular}{|c|c|c|c|c|c|c|c|c|c|c|c|c|}
\hline \multirow{2}{*}{ Questions } & \multirow{2}{*}{$\begin{array}{l}\text { Innovation } \\
\quad(\mathrm{X} 1)\end{array}$} & \multicolumn{2}{|c|}{$\mathbf{1}$} & \multicolumn{2}{|c|}{2} & \multicolumn{2}{|c|}{3} & \multicolumn{2}{|l|}{4} & \multicolumn{2}{|c|}{5} & \multirow{2}{*}{$\begin{array}{c}\text { Index } \\
(\%)\end{array}$} \\
\hline & & $\mathbf{F}$ & $\%$ & $\mathbf{F}$ & $\%$ & $\mathbf{F}$ & $\%$ & $\mathbf{F}$ & $\%$ & $\mathbf{F}$ & $\%$ & \\
\hline 1. Improve product / service quality & INV 1 & 6 & 10 & 8 & 13 & 21 & 35 & 17 & 28 & 8 & 13 & 64 \\
\hline 2. Unique and attractive product designs & INV 2 & 5 & 8 & 11 & 18 & 18 & 30 & 19 & 32 & 7 & 12 & 64 \\
\hline 3. Unique and attractive packaging & INV 3 & 5 & 8 & 9 & 15 & 21 & 35 & 18 & 30 & 7 & 12 & 64 \\
\hline 4. There are various sizes available & INV 4 & 7 & 12 & 8 & 13 & 28 & 47 & 11 & 18 & 6 & 10 & 60 \\
\hline 5. Using technology services & INV 5 & 6 & 10 & 8 & 13 & 22 & 37 & 15 & 25 & 9 & 15 & 64 \\
\hline 6. Different ways of payment & INV 6 & 5 & 8 & 9 & 15 & 22 & 37 & 17 & 28 & 7 & 12 & 64 \\
\hline 7. Technological payment methods & INV 7 & 3 & 5 & 16 & 27 & 20 & 33 & 15 & 25 & 6 & 10 & 62 \\
\hline 8. The production process uses technology & INV 8 & 1 & 2 & 13 & 22 & 20 & 33 & 18 & 30 & 8 & 13 & 66 \\
\hline $\begin{array}{l}\text { 9. Professional and innovative in serving } \\
\text { customers }\end{array}$ & INV 9 & 2 & 3 & 11 & 18 & 24 & 40 & 13 & 22 & 10 & 17 & 66 \\
\hline 10. Make changes in business practices & INV10 & 4 & 7 & 12 & 20 & 21 & 35 & 16 & 27 & 7 & 12 & 63 \\
\hline 11. Improve the company's external relations & INV11 & 4 & 7 & 11 & 18 & 19 & 32 & 16 & 27 & 10 & 17 & 66 \\
\hline 12. Has a network (net work/social media) & INV12 & 5 & 8 & 10 & 17 & 18 & 30 & 17 & 28 & 10 & 17 & 66 \\
\hline $\begin{array}{l}\text { 13. Dare to take risks on changing business } \\
\text { models }\end{array}$ & NV13 & 5 & 8 & 5 & 8 & 18 & 30 & 24 & 40 & 8 & 13 & 68 \\
\hline & & & & & & & & & & & & 64 \\
\hline
\end{tabular}

Source: Data processed

Based on the table, the average total index on the innovation variable is $64 \%$, meaning that it has a moderate index. In this study, the innovation variable is considered almost in accordance with the respondents' perceptions, thus giving responses with a moderate score on the statement item.

b. Index Analysis of Respondents' Answers on Entrepreneurship Variables

The entrepreneurship variable in this study was measured by 10 statements in the dimensions of pro-activeness, acceptance of risks and collective business capacity. The results of the calculation of answers and index scores towards the entrepreneurship variable can be seen in the following table:

Table 7. Results of Respondents' Answer to Entrepreneurship Variables

\begin{tabular}{|c|c|c|c|c|c|c|c|c|c|c|c|c|}
\hline \multirow[t]{2}{*}{ Questions } & \multirow{2}{*}{$\begin{array}{l}\text { Entrepre- } \\
\text { neurship } \\
\text { (X2) }\end{array}$} & \multirow{2}{*}{$\begin{array}{c}1 \\
\mathbf{F}\end{array}$} & \multicolumn{3}{|c|}{2} & \multirow{2}{*}{$\begin{array}{l}3 \\
\mathbf{F}\end{array}$} & \multicolumn{2}{|c|}{4} & \multicolumn{2}{|c|}{5} & \multicolumn{2}{|c|}{$\begin{array}{c}\text { Index } \\
(\%)\end{array}$} \\
\hline & & & $\%$ & $\mathbf{F}$ & $\%$ & & $\%$ & $\mathbf{F}$ & $\%$ & $\mathbf{F}$ & $\%$ & \\
\hline $\begin{array}{l}\text { 1. Monitoring the macro } \\
\text { environment }\end{array}$ & KWR1 & 3 & 5 & 5 & 8 & 10 & 17 & 14 & 23 & 28 & 47 & 80 \\
\hline $\begin{array}{l}\text { 2. Being able to follow up on new } \\
\text { opportunities }\end{array}$ & KWR2 & 6 & 10 & 3 & 5 & 9 & 15 & 12 & 20 & 30 & 50 & 79 \\
\hline $\begin{array}{l}\text { 3. Participate in local, regional and } \\
\text { international markets }\end{array}$ & KWR3 & 1 & 2 & 5 & 8 & 13 & 22 & 17 & 28 & 24 & 40 & 79 \\
\hline 4. Able to accept risk & KWR4 & 2 & 3 & 6 & 10 & 13 & 22 & 16 & 27 & 23 & 38 & 77 \\
\hline $\begin{array}{l}\text { 5. Able to make investment } \\
\text { decisions }\end{array}$ & KWR5 & 2 & 3 & 7 & 12 & 12 & 20 & 18 & 30 & 21 & 35 & 76 \\
\hline $\begin{array}{l}\text { 6. Able to take strategic actions in } \\
\text { uncertainty }\end{array}$ & KWR6 & 6 & 10 & 1 & 2 & 17 & 28 & 21 & 35 & 15 & 25 & 73 \\
\hline
\end{tabular}


Suharyati ${ }^{1)}$, Edimarwan ${ }^{2)}$, Strengthening Innovation And Entrepreneurship In Improving Msmes Competitiveness

\begin{tabular}{|l|c|ccccccccccc|} 
7. Able to work in team & KWR7 & 5 & 8 & 2 & 3 & 28 & 47 & 12 & 20 & 13 & 22 & 69 \\
\hline 8. Able to communicate & KWR8 & 5 & 8 & 3 & 5 & 28 & 47 & 10 & 17 & 14 & 23 & 68 \\
\hline 9. Interpersonal skills & KWR9 & 8 & 13 & 9 & 15 & 19 & 32 & 15 & 25 & 9 & 15 & 63 \\
\hline $\begin{array}{l}\text { 10. Being able to involve the team } \\
\text { in seizing opportunities }\end{array}$ & KWR10 & 4 & 7 & 5 & 8 & 26 & 43 & 17 & 28 & 8 & 13 & 67 \\
\hline \multicolumn{1}{|c|}{ Average Index } & & & & & 73 \\
\hline
\end{tabular}

Source: Data processed

Based on the table, the average total index on the entrepreneurship variable is $73 \%$, meaning that it has a high index. In this study, the entrepreneurship variable is considered in line with the respondents' perceptions, so that it gives a response with a high score on the statement item.

c. Index Analysis of Respondents' Answers on Competitiveness Variables

The competitiveness variable in this study is measured by 12 statements with indicators of financial access, human resources, market access, product competitiveness, product efficiency, organizational efficiency, infrastructures and business climate. The results of calculation of the answers and index scores towards the competitiveness variable can be seen in the following table:

Table 8. Results of Respondents' Answers Against Variables Competitiveness

\begin{tabular}{|c|c|c|c|c|c|c|c|c|c|c|c|c|}
\hline \multirow{2}{*}{ Questions } & \multirow{2}{*}{$\begin{array}{l}\text { Competi- } \\
\text { tiveness } \\
(\mathbf{Y})\end{array}$} & \multicolumn{2}{|c|}{1} & \multicolumn{2}{|c|}{2} & \multicolumn{2}{|c|}{3} & \multicolumn{2}{|l|}{4} & \multicolumn{2}{|c|}{5} & \multirow[t]{2}{*}{$\begin{array}{c}\text { Index } \\
(\%)\end{array}$} \\
\hline & & $\mathbf{F}$ & $\%$ & $\mathbf{F}$ & $\%$ & $\mathbf{F}$ & $\%$ & $\mathbf{F}$ & $\%$ & $\mathbf{F}$ & $\%$ & \\
\hline $\begin{array}{l}\text { 1. MSMEs have good financial support tin } \\
\text { running their business }\end{array}$ & DYS1 & 7 & 12 & 11 & 18 & 22 & 37 & 19 & 32 & 1 & 2 & 59 \\
\hline $\begin{array}{l}\text { 2. The capital of MSMEs are helped by the } \\
\text { existence of fintech }\end{array}$ & DYS2 & 4 & 7 & 7 & 12 & 29 & 48 & 17 & 28 & 3 & 5 & 63 \\
\hline $\begin{array}{l}\text { 3. Entrepreneurs are able to lead their } \\
\text { companies }\end{array}$ & DYS3 & 4 & 7 & 10 & 17 & 18 & 30 & 20 & 33 & 8 & 13 & 66 \\
\hline $\begin{array}{l}\text { 4. Entrepreneurs have good understanding } \\
\text { in business/economic growth }\end{array}$ & DYS4 & 6 & 10 & 4 & 7 & 19 & 32 & 18 & 30 & 13 & 22 & 69 \\
\hline $\begin{array}{l}\text { 5. Entrepreneurs are innovative in taking } \\
\text { every action }\end{array}$ & DYS5 & 4 & 7 & 8 & 13 & 20 & 33 & 18 & 30 & 10 & 17 & 67 \\
\hline $\begin{array}{l}\text { 6. The local government supports the } \\
\text { availability of MSME outlets, } \\
\text { exhibitions and displays. }\end{array}$ & DYS6 & 4 & 7 & 3 & 5 & 20 & 33 & 16 & 27 & 17 & 28 & 73 \\
\hline 7. Products have good competitiveness & DYS7 & 5 & 8 & 7 & 12 & 22 & 37 & 17 & 28 & 9 & 15 & 66 \\
\hline 8. The production process runs efficiently & DYS8 & 2 & 3 & 10 & 17 & 26 & 43 & 14 & 23 & 8 & 13 & 65 \\
\hline $\begin{array}{l}\text { 9. MSME business organization is } \\
\text { implemented according to the plan, so it } \\
\text { runs efficiency }\end{array}$ & DYS9 & 8 & 13 & 11 & 18 & 18 & 30 & 11 & 18 & 12 & 20 & 63 \\
\hline $\begin{array}{l}\text { 10. The government facilitates various } \\
\text { infrastructure needed by MSMEs }\end{array}$ & DYS10 & 9 & 15 & 7 & 12 & 22 & 37 & 16 & 27 & 6 & 10 & 61 \\
\hline $\begin{array}{l}\text { 11. Entrepreneurs have knowledge about } \\
\text { business/economic growth }\end{array}$ & DYS11 & 5 & 8 & 8 & 13 & 22 & 37 & 18 & 30 & 7 & 12 & 65 \\
\hline $\begin{array}{l}\text { 12. A conducive business climate } \\
\text { encourages sales }\end{array}$ & DYS12 & 3 & 5 & 11 & 18 & 26 & 43 & 12 & 20 & 8 & 13 & 64 \\
\hline & & & & & & & & & & & & 65 \\
\hline
\end{tabular}

Source: Data Processed 
Based on the table, the average total index on the competitiveness variable is $65 \%$, meaning that it has a moderate index. In this study, the competitiveness variable is considered to be almost in line with the respondents' perceptions, thus giving a response with a moderate score on the statement item.

\section{Data analysis and Hypothesis Test}

The data analysis technique used in this research is the validity and reliability tests followed by the hypothesis test by using SmartPLS software version 3.2.8 which is processed using two models, namely the measurement model (outer model) and the structural model (inner model). This study uses a sample of 60 respondents so that the results obtained are valid and reliable.

\section{Estimation of Outer Model dan Inner Model}

The results of the SmartPLS software on the estimation of the outer model and the inner model are obtained as shown in Figure 5.

Figure 3. Path Chart of Inner and Outer Model

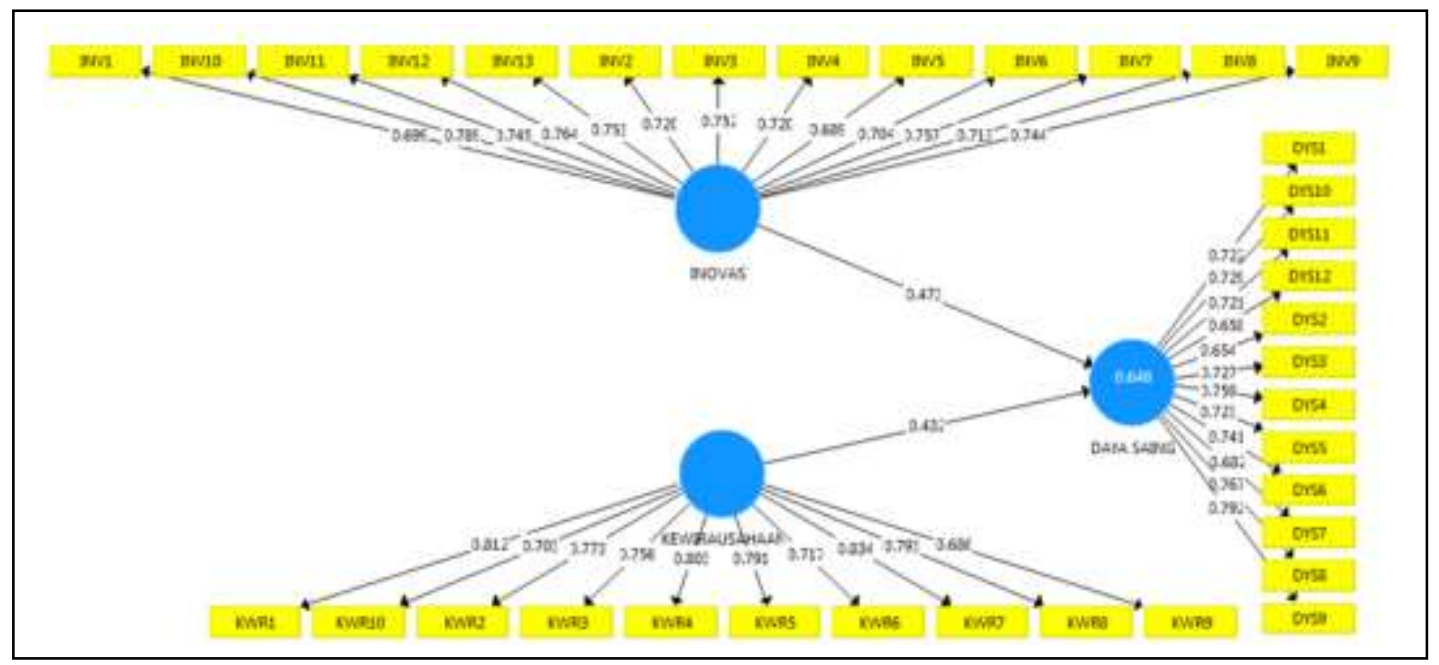

Source: SmartPLSversion Output 3.2.8

Figure of path diagram can be interpreted into the table as follows:

Table 9. Outer Model Result

\begin{tabular}{cccccc}
\hline \multicolumn{2}{c}{ Innovation (X1) } & \multicolumn{2}{c}{ Entrepreneurship (X2) } & \multicolumn{2}{c}{ Competitiveness(Y) } \\
\hline INV1 & 0.699 & KWR1 & 0.812 & DYS1 & 0.722 \\
\hline INV10 & 0.789 & KWR10 & 0.703 & DYS10 & 0.729 \\
\hline INV11 & 0.745 & KWR2 & 0.773 & DYS11 & 0.721 \\
\hline INV12 & 0.764 & KWR3 & 0.756 & DYS12 & 0.658 \\
\hline INV13 & 0.753 & KWR4 & 0.803 & DYS2 & $\mathbf{0 . 6 5 4}$ \\
\hline INV2 & 0.720 & KWR5 & 0.791 & DYS3 & 0.727 \\
\hline INV3 & 0.752 & KWR6 & 0.717 & DYS4 & 0.759 \\
\hline INV4 & 0.720 & KWR7 & $\mathbf{0 . 8 3 4}$ & DYS5 & 0.723 \\
\hline INV5 & 0.689 & KWR8 & 0.793 & DYS6 & 0.741 \\
\hline INV6 & 0.704 & KWR9 & 0.686 & DYS7 & 0.682 \\
\hline INV7 & 0.757 & & & DYS8 & 0.767 \\
\hline INV8 & 0.713 & & DYS9 & 0.792 \\
\hline INV9 & 0.744 & & & \\
\hline
\end{tabular}




\section{Source: SmartPLS}

Based on the table, the entrepreneurship variable has the greatest loading factor value in the KWR7 statement item with a value of 0.834 and the smallest value is in the DYS12 statement item with a value of 0.654 .

\section{Goodness Of Fit Evaluation}

\section{Outer Model}

\section{Convergent Validity Test}

The result of SmartPLS software, shows the loading factor value for each indicator of each construct:

Table 10. Outer Loading FactorResult

\begin{tabular}{|c|c|c|c|}
\hline & Innovation (X1) & Entrepreneurship (X2) & Competitiveness (Y) \\
\hline INV1 & 0.699 & & \\
\hline INV10 & 0.789 & & \\
\hline INV11 & 0.745 & & \\
\hline INV12 & 0.764 & & \\
\hline INV13 & 0.753 & & \\
\hline INV2 & 0.720 & & \\
\hline INV3 & 0.752 & & \\
\hline INV4 & 0.72 & & \\
\hline INV5 & 0.689 & & \\
\hline INV6 & 0.704 & & \\
\hline INV7 & 0.757 & & \\
\hline INV8 & 0.713 & & \\
\hline INV9 & 0.744 & & \\
\hline KWR1 & & 0.812 & \\
\hline KWR10 & & 0.703 & \\
\hline KWR2 & & 0.773 & \\
\hline KWR3 & & 0.756 & \\
\hline KWR4 & & 0.803 & \\
\hline KWR5 & & 0.791 & \\
\hline KWR6 & & 0.717 & \\
\hline KWR7 & & 0.834 & \\
\hline KWR8 & & 0.793 & \\
\hline KWR9 & & 0.686 & \\
\hline DYS1 & & & 0.722 \\
\hline DYS10 & & & 0.729 \\
\hline DYS11 & & & 0.721 \\
\hline DYS12 & & & 0.658 \\
\hline DYS2 & & & 0.654 \\
\hline DYS3 & & & 0.727 \\
\hline DYS4 & & & 0.759 \\
\hline DYS5 & & & 0.723 \\
\hline DYS6 & & & 0.741 \\
\hline DYS7 & & & 0.682 \\
\hline DYS8 & & & 0.767 \\
\hline DYS9 & & & 0.792 \\
\hline
\end{tabular}

Source: SmartPLSversion Output 3.2.8

The criteria for fulfilling convergent validity if the factor load value is greater or equal to 0.5 to 0.6 (factor loading $\geq 0.5$ - 0.6). It was concluded that all indicators on all variables of this study could be used because it had met the convergent validity test with values equal to or more than $(\geq) 0.5$.

\section{Discriminant Validity}

The output of SmartPLS software, fornell-lacker criterium values for each indicator as follows: 
Table 11. Fornell-Lacker Criterium

\begin{tabular}{lccc}
\hline & Innovation (X1) & Entrepreneurship (X2) & Competitiveness (Y) \\
\hline Innovation (X1) & 0.735 & & \\
\hline $\begin{array}{l}\text { Entrepreneurship } \\
\text { (X2) }\end{array}$ & 0.582 & 0.768 & \\
\hline Competitiveness (Y) & 0.725 & 0.707 & 0.724 \\
\hline Source: Smart PLSversion Output 3.2.8 & &
\end{tabular}

It can be seen that the discriminant validity test through the fornell-lacker criterium table has values above 0.6 for all variables. Another method that can be used to see the discriminant validity is to consider the Average Variance Extracted (AVE) value.

The result of SmartPLS, obtained AVE values for each indicator:

Table 12. Average Variance Extracted (AVE)

\begin{tabular}{lc}
\hline & Average Variance Extracted $(\boldsymbol{A V E})$ \\
\hline Innovation (X1) & 0.540 \\
\hline Entrepreneurship (X2) & 0.590 \\
\hline Competitiveness (Y) & 0.524 \\
\hline Source: SmartPLSversion Output 3.2.8
\end{tabular}

The result above shows that the AVE value exceeds 0.5 or above the number (>) 0.50 for the entire construct contained in the research model.

\section{Composite Reability}

The result of SmartPLS software obtained composite reliability values as follows: Table 13. Composite Reliability

\begin{tabular}{lc}
\hline & Composite Reliability \\
\hline Innovation (X1) & 0.938 \\
\hline Entrepreneurship (X2) & 0.935 \\
\hline Competitiveness (Y) & 0.929 \\
\hline Source: SmartPLSversion Output 3.2.8
\end{tabular}

The suggested value on composite reliability is greater or equal to $(\geq) 0.7$ and the test results show the composite reliability value for all constructs is more than (>) 0.7 meaning that all constructs in the estimated model meet the criteria.

\section{Cronbach's Alpha}

The result of SmartPLS software shows that the cronbach's alpha value is:

Table 14. Cronbach's Alpha

\begin{tabular}{lc}
\hline & Cronbach's Alpha \\
\hline Innovation (X1) & 0.929 \\
\hline Entrepreneurship (X2) & 0.923 \\
\hline Competitiveness (Y) & 0.917 \\
\hline Source: SmartPLSversion Output 3.2.8 &
\end{tabular}


The construct is stated to be reliable if the value of Cronbach's alpha is above (>) 0.7. The test results show that the Cronbach's alpha value for all constructs is above $(>)$ 0.7 .

\section{Inner Model}

The output of SmartPLS software obtained inner model values:

Figure 4. Inner Model

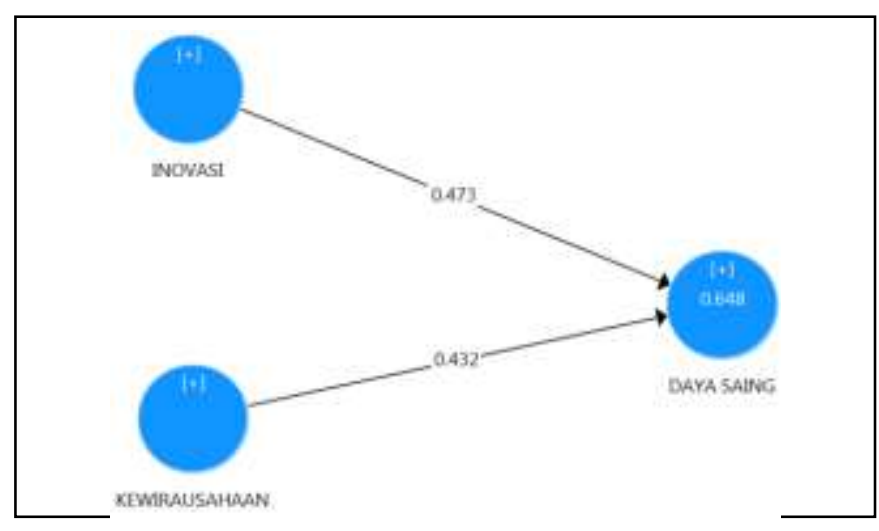

Source: SmartPLSversion Output 3.2.8

Based on the picture above it is known that the inner model value, the relationship of innovation and competitiveness is 0.473 while the relationship between entrepreneurship and competitiveness is 0.432 .

\section{R-square $\left(\mathbf{R}^{2}\right)$}

$\mathrm{R}$-square test is one of the goodness fit inner model tests. Here the R-Square is used to determine the contribution of independent variables to the dependent variable. The output of SmartPLS is described as follows:

Table 15. R-square

\begin{tabular}{lcc}
\hline & $\boldsymbol{R}$ Square & $\boldsymbol{R}$ Square Adjusted \\
\hline Competitiveness (Y) & 0.648 & 0.636 \\
\hline \multicolumn{2}{l}{ Source: SmartPLSversion Output 3.2.8 }
\end{tabular}

Based on the table above, it can be seen that the amount of $\mathrm{R}$ Square on the competitiveness variable shows the contribution of the influence of innovation and entrepreneurship variables on competitiveness is around $64.8 \%$ and the rest is influenced by other factors that are not examined in this study.

\section{$Q$-square}

Q-Square predictive relevance for structural models, measuring how well the value of observations produced by the model and also the estimated parameters. QSquare value $>0$ indicates that the model has predictive relevance, on the contrary, if the $\mathrm{Q}$-square value $\leq 0 . \mathrm{Q}^{2}$ is the coefficient of total determination in the path analysis. The quantity $\mathrm{Q}^{2}$ has a range value of $0<\mathrm{Q}^{2}<1$, where getting closer to 1 means the model is getting better. 
The results show $\mathrm{Q}^{2}=1-\left(1-\mathrm{R} 1^{2}\right)=1-\left(1-0.648^{2}\right)=0.480$, so it can be interpreted that the structure of the research model is good and has conformity.

\section{T-statistic test}

The results of the SmartPLS obtained the value of the path coefficients as follows:

Table 16. Results of Path Analysis Coefficient Values

\begin{tabular}{lccc}
\hline & $\begin{array}{c}\text { Original } \\
\text { Sample }(\mathbf{O})\end{array}$ & $\begin{array}{c}\text { T Statistics } \\
(\mid \mathbf{O} / \mathbf{S T D E V})\end{array}$ & P Values \\
\hline Innovation -> Competitiveness & 0.473 & 4.772 & 0.000 \\
\hline $\begin{array}{l}\text { Entrepreneurship }-> \\
\text { Competitiveness }\end{array}$ & 0.432 & 4.142 & 0.000 \\
\hline Source: SmartPLSversion Output 3.2.8 & &
\end{tabular}

Based on the table above as illustrated in the Original Sample $(\mathrm{O})$ column, it can be concluded that the innovation testing on competitiveness shows a positive effect with a value of 0.473 or $47.3 \%$. Known t table $=2.003$ with a degree of confidence of $5 \%$ or 0.05 so that the $\mathrm{t}$ count shows a value of $4.772>\mathrm{t}$ table 2.003 and a significant value of $0.000<0.05$, which means that innovation has a significant effect on competitiveness.

Then the entrepreneurship test on competitiveness indicates a positive effect with a value of 0.432 or $43.2 \%$. The test results show the value of $t_{\text {count }} 4.142>t$ table 2.003 and a significant value of $0.000<0.05$ which means that entrepreneurship has a significant effect on competitiveness.

\section{Discussion}

\section{The Influence of Innovation on Competitiveness}

Hypothesis testing result signifies that the innovation has a positive and significant direct effect of $47.3 \%$ on competitiveness so that the hypothesis that has been built previously is accepted or $\mathrm{H}_{1}$ is accepted. This is proved by the great number of the path coefficient of 0.473 which shows that the direction of the relationship between innovation and entrepreneurship is positive. Whereas the t-statistic test shows the value of $t_{\text {count }}>t_{\text {table }} 2.003$ and a significant value of $0.000<\alpha$ indicates that innovation has a significant effect on competitiveness.

In line with the research of (Andriyanto, 2018) the use of IT in implementing ecommerce is a competitive strategy and increases MSME competitiveness. (Muslikh, 2015) Innovation has a significant influence on competitiveness. (Haryono \& Marniyati, 2017) this research result shows that there is positive and significant direct influence on the competitiveness of product innovation. (Baer, 2019) explain about 3 types of innovation, which are: Product, Process, and Business Model. Companies that implement innovation in their products, processes and business models will have an impact on the competitive advantage which will encourage companies to have competitiveness. Likewise, MSMEs that have implemented innovations in their business activities will have competitiveness at both the national and global levels. Thus in line with the results of this study, related theory support and previous research results where innovation with indicators in the form of product innovation, process innovation, business model innovation, has a positive and significant direct influence on the competitiveness of MSMEs, increasing innovation for MSMEs will have an impact on improving the competitiveness of MSMEs at both the national and global levels. 


\section{The influence of Entrepreneurship on Competitiveness}

The results of hypothesis testing show that entrepreneurship has a positive and significant direct effect of $43.2 \%$ on competitiveness so that the hypothesis that has been built previously is accepted or $\mathrm{H}_{2}$ is accepted. This is evidenced by the great number of the path coefficient of 0.432 which indicates that the direction of the relationship between entrepreneurship and competitiveness is positive. Whereas the $\mathrm{t}-$ statistic test shows the value of $t_{\text {count }}>t_{\text {table }} 2.003$ and the significant value of $0.000<\alpha$ indicates that entrepreneurship has a significant effect on competitiveness.

In line with the research of (Yanah, Nakhwatunnisa, \& Sukarno, 2018) where the variable funding, entrepreneurship training, business mentoring and partnerships have a positive and significant effect on the competitiveness of SMEs in the face of the ASEAN economy. (Muslikh, 2015), Entrepreneurial orientation has a significant influence on innovation, and innovation has a significant influence on competitiveness. (Fatmawati, Pradhanawati, \& Ngatno, 2016) the results of the study show that there is an influence on entrepreneurial orientation towards competitiveness. Likewise, in line with the research of Dahlia, Meidylisa Patty and Dian Utami Sutiksno, 2015, it can be concluded that the influence of positive variables on the competence of entrepreneurs, the use of information technology, and innovation towards the competitiveness in approaching the ASEAN Economic Community 2015. (Badriah, 2015) Competitiveness is an absolute requirement that should be owned by Indonesia in facing Globalization. To support competitiveness it is necessary to emphasize the importance of competitive advantage. To be able to create a competitive advantage, 3 things are needed, which are knowledge, creativity, and innovation.

Based on the results of research, theoretical support and previous research shows that entrepreneurship has a positive and significant effect directly on competitiveness, with the indicators of entrepreneurship in the form of pro-activeness, acceptance of risks, collective business capacity, this explains that the improvement of entrepreneurship will influence the increase in competitiveness of MSMEs both at national and global level.

\section{Conclusion}

Based on the results of research and hypothesis testing that has been done through the SmartPLS, analysis regarding strengthening innovation and entrepreneurship in improving MSME competitiveness, it can be concluded that innovation with indicators in the form of product innovation, process innovation, business model innovation, directly contributes on the competitiveness of MSMEs, increasing innovation for MSMEs will have an impact on increasing MSME competitiveness. Entrepreneurship with indicators in the form of pro-activeness, acceptance of risks, collective business capacity contributes directly to competitiveness. This explains that the increase in entrepreneurship will influence the improvement of MSME competitiveness.

\section{References}

Ahmedova, S. (2015). Factors for Increasing the Competitiveness of Small and Medium Sized Enterprises (SMEs) In Bulgaria. Procedia - Social and Behavioral Siences. Retrieved from www.sciencedirect.com, http://creativecommons.org /licenses/by-nc-nd/4.0/ 
Andriyanto, I. (2018, dec 6). Penguatan Daya Saing Usaha Mikro Kecil Menengah Melalui E-Commerce. BISNIS, 6 (2). Retrieved from http://journal.stainkudus.ac.id/index.php/Bisnis/article/view/4709

$\begin{array}{lllll}\text { Auliani, } & \text { P. } & \text { A. } & \text { Juli). }\end{array}$ https://ekonomi.kompas.com/read/2018/07/04/161334926/geliat-umkm-dan-eradisrupsi. Retrieved Februari Minggu,3, 2019

Badriah, L. S. (2015). Pengembangan Inovasi dan Kewirausahaan Sebagai Upaya Menghadapi Era Masyarakat Ekonomi ASEAN 2015. Retrieved from http://jp.feb.unsoed.ac.id/index.php/sca-1/article/viewFile/655/688

Baer, S. (2019). The 3 Types of Innovation: Product, Process, \& Business Model. Retrieved Jun Thursday,13 , 2019, from https://differential.com/insights/the3typesofinnovation/

Bank Indonesia. (2016). Pemetaan Dan Strategi Peningkatan Daya Saing UMKM Dalam Menghadapi Masyarakat Ekonomi ASEAN (MEA) 2015 Dan Pasca MEA 2025. Jakarta: Departemen Pengembangan UMKM Bank Indonesia .

Brown, T. E., \& Ulijn, J. ( 2004). Innovation, entrepreneurship and culture: the interaction between technology, progress and economic growth. MPG Books Ltd, Bodmin, Cornwall.

Budianto, A. (2018, Sep 21). 8-juta-umkm-bertransaksi-online-pada-2019. Retrieved from https://jabar.sindonews.com

Burger, T.-H. (2012). Entrepreneurship - Creativity and Innovative Business Models. (I. J. Edited, Ed.) Croatia. ISBN 978-0470-45037-6 (pbk).

Dahlia, Patty, M., \& Sutiksno, D. U. (2015). Peningkatan Daya Saing dalam Menghadapi Asean Economic Community (AEC) 2015. Jurnal unpad. Dipetik Februari 02, 2019

David, F. r., \& David, F. r. (2017). Strategic Management: A Competitive Advantage Approach, Concepts and Cases (16th ed.). USA: Pearson Education.

Dollinger, M. J. (2008). Entrepreneurship: strategies and resources. USA: Pearson Education Inc.

Drucker, P. F. (1986). Innovation and Enterpreneurship. New York, USA: Harper Collins Publishers, Inc-1993.

Dwi.R, H. (2017, Agustus). https://www.kompasiana.com/peran-penting-umkmpenggerak-penting-ekonomi-indonesia. Retrieved Februari Sabtu, 2, 2019

Fatmawati, R. A., Pradhanawati, A., \& Ngatno, N. (2016). Pengaruh Orientasi Kewirausahaan terhadap Keunggulan Bersaing Pada Warung Kucingan/Angkringan Di Kota Semarang. 5(3). Retrieved from https://ejournal3.undip.ac.id/index.php/jiab/article/view/12526

Haryono, T., \& Marniyati, S. (2017). Pengaruh Market Orientation, Inovasi Produk, dan Kualitas Produk Terhadap Kinerja Bisnis Dalam Menciptakan Keunggulan Bersaing. Jurnal Bisnis \& Manajemen , 17(2), 51 -68. Retrieved from https://jurnal.uns.ac.id

Hitt, M. A., Duane, I. R., \& Hoskisson, R. E. (2009). Strategic Management : Competitiveness and Globalization (Concepts and Cases). USA: South-Weatern Cengage Learning.

Kotler, P., \& Keller, K. L. (2012). Marketing Management (Vol. 14). USA: Prentice Hall.

Kuratko, D. F., Frederich, \& O'Connor, H. A. (2016). Entrepreneurship: theory/process/practice (4th edition ed.). South Melbourne, Victoria, Australia : Cengage Leaming Australia Pty Limited. 
Mariotti, S. (2010). Entrepreneurship: Owning Your Future, (11th ed.). New Jersey: Pearson Education. Retrieved from www.pearsonhighered.com

Merdeka, (2018, Juli). https://www.liputan6.com/bisnis/read/3581067/umkm-sumbang60-persen-ke-pertumbuhan-ekonomi-nasional. Retrieved Februari Minggu,3, 2019

Muslikh. (2015). Upaya Menungkatkan Daya Saing Produk UMKM di Kampung Wisata Tegal Waru Kabupaten Bogor. Retrieved October 2018, from http://pustaka.unpad.ac.id

Mutmainah, D. A. (2016, Nov Monday, 21). Kontribusi UMKM Terhadap PDB Tembus Lebih Dari 60 Persen. Retrieved Feb 10, 2019, from https://www.cnnindonesia.com

Nurzamzami, A., \& Siregar, E. H. (2014, April). Peningkatan Daya Saing UMKM Alas Kaki di Kecamatan Ciomas, Kabupaten Bogor dan Implikasinya terhadap Strategi Pemasaran. Jurnal Manajemen dan Organisasi,V(1).Retrieved fromhttps://journal.ipb.ac.id/index.php/jmo/article/view/12127

Pavlova, D., \& Ahmedova, S. (2017, Dec 28). Opportunities for forming competitive advantages through transfer of technology. , 1 (1). doi: DOI: 10.29114/ajtuv.vol1.iss 1.32

Porter, M. E. (1998). Competitive strategy : techniques for analyzing industries and competitors. New York, USA: The Free Press All Rights Reserved.

Purnomo, A. (2017, April 2). Penguatan Kewirausahaan Dalam Meningkatkan Daya Saing UKM Produk Unggulan Di Kota Bandar Lampung. jurnal sosialita . Retrieved from http://jurnal.ubl.ac.id/index.php/JIA/article/view/860

Putra, D. A. (2018, Jul 06). umkm-sumbang-60-persen-ke-pertumbuhan-ekonominasional. Retrieved Jan 30, 2019, from https://www.liputan6.com

Putra, H. (2018). wow-go-jek-percepat-pertumbuhan-lebih-dari-442-ribu-umkm. Retrieved 08 29, 2018, from http://wartakota.tribunnews.com

Ramadhan, B. $\quad$ (2017, October https://www.goodnewsfromindonesia.id/2017/10/04/tingkat-daya-saing-negaranegara-dunia-tahun-2017-2018. (W. E. (WEF), Producer) Retrieved September 28, 2019

Ramadhan, I. (2017, Des 13). forum-umkm-tingkatkan-kesejahteraan-pelaku-usahalewat-family-gathering. Retrieved Jan 30, 2019, from http://www.heibogor.com

Republika. (2018). kabupaten Bogor komit kembangkan umkm. Republika. Retrieved September 2018, from https://www.republika.co.id

Robbins, S. P., \& Coulter, M. (2016). Management (Vol. 13th Edition). published by Pearson Education.

Rogers, E. M. ( 2003). Diffusion of innovations.

Sandy, K. F. (2016). Peningkatan Daya Saing UMKM Mendorong Pertumbuhan Ekonomi. Jakarta: ekbis.sindonews.com. Retrieved 2016, from https://ekbis.sindonews.com/read/1139470/34/

Scarborough, N. M. (2012). Effective small business management : an entrepreneurial approach (Vol. 10). USA, New Jersey: Pearson Education, Inc.,publishing as Prentice Hall.

SINDO, K. (2016, Sep Friday, 16). Daya Saing UMKM Perlu Ditingkatkan,. Retrieved Feb 10, 2019, from https://economy.okezone.com

Sopia, S. (2017, Jan 04). Daya Beli Warga Kabupaten Bogor Didorong Lewat UMKM. (E. Yuwanto, Ed.) Retrieved from https://www.republika.co.id 
Suharyati, \& Ediwarman. (2019, February, 2). Economic Potential Mapping in Parung Subdistrict, Bogor District. International Journal of Multicultural and Multireligious Understanding, 6(2), 1-17. Retrieved from http://ijmmu.com

Sumaryono. (2017, Januari Kamis, 12). https://www.beritasatu.com/investor/408921memacu-daya-saing-umkm.html. Retrieved Februari Sabtu, 2018

Sutrisno, D. (2016, Nov 21). umkm-berperan-memerangi-kemiskinan-danpengangguran. (N. Zuraya, Ed.) Retrieved Jan 30, 2019, from https://www.republika.co.id

White, M. A., \& Bruton, G. D. (2011). The Management of Technology and Innovation : A Strategic Approach. USA: South Western Cengage Learning.

Yanah, Nakhwatunnisa, H., \& Sukarno, T. A. (2018). Strategy to Increase the Competitiveness of SME's Entreprises. Jejak, 11 (1), 138-150. doi:DOI: https://doi.org/10.15294/jejak

Yasmin, P. A. (2018, July Selasa, 17). https://finance.detik.com/berita-ekonomibisnis/d-4119386/jadi-penggerak-ekonomi-begini-kondisi-umkm-ri. Retrieved Februari Minggu, 10, 2019

Zaidi, A. (2018). Three Types Innovation. Jakarta. Retrieved May 05, 2018, from http://mdi.com.pk/management/2018/05/three-types-innovation/

Zhao, F. (2006). Entrepreneurship and innovations in e-business : an integrative perspective . United States of America : Idea Group Publishing. 